\title{
Goode, J., ed. (2019) Clever Girls: Autoethnographies of Class, Gender, and Ethnicity. Palgrave Macmillan.
}

\section{Review by Christie Launius}

This ambitious volume, a co-recipient of the 2020 Jake Ryan Award for books about the working-class academic experience, is the latest in a long line of collections that highlight the voices of those who have achieved some measure of upward class mobility via higher education. Editor and contributor Jackie Goode has brought together fourteen writers in this collection. In addition to contributing her own narrative essay that recounts her experiences of family, schooling, and upward mobility, Goode wrote an extensive Introduction and Conclusion, as well as two substantial scholarly essays, 'The Classed, Gendered, and Racialised Subject,' and 'On Autoethnography.' This volume, then, not only contributes a remarkably diverse array of narrative essays, but also makes a significant contribution to the scholarship on narratives of upward class mobility achieved via higher education. It's like the best kind of 'buy one get one free' deal, whether your primary interest is in the narrative essays themselves or the theoretical discourses on subjectivity and the methods of autoethnography.

As the title suggests, all of the contributors are women, and a primary focus of their narratives is their experience of being 'clever girls,' working-class girls who were marked out for their 'cleverness.' In her Preface, Goode provides the British lineage of this kind of autoethnographic writing about class, education, and upward mobility, some of which may be unfamiliar to readers outside the UK. She cites Hoggart's The Uses of Literacy, Liz Heron's Truth, Dare, or Promise, Heidi Safia Mirza's Young, Female, and Black, Bev Skeggs' Formations of Class and Gender, Mahony and Zmroczek's Class Matters, and Valerie Walkerdine's Growing Up Girl. There is an extensive companion literature in the U.S (for an overview, see Warnock 2016); two notable volumes that focus on gender in particular are Tokarczyk and Fay's Working-Class Women in the Academy (1993) and Those Winter Sundays: Female Academics and Their Working-Class Parents (2004).

A strength of the volume is that Goode very intentionally solicited narrative essays by women across multiple generations, or as she puts it, the collection contains a 'temporal component' that 'trac[es] continuities and change across generations through stories from the children of the Welfare State/Butler's 1944 Education Act; Thatcher/Blair's children; and Cameron/May/Johnson's post-EU referendum/Trump-era children' (p. x). The narrative essays are presented chronologically, with the eldest writers appearing first. Claire Mitchell's essay appears toward the end of the volume, marking her as among the youngest contributors. While all of the narratives recount struggles of many kinds, Mitchell's essay stands out from the rest for her revelation that in spite of all her striving, the acquisition of educational credentials has not brought about the desired upward mobility. She writes movingly about her experiences growing up with a single mother who went to university at the age of 27 . Claire follows in her mother's footsteps, attending university, and they both earn undergraduate and master's degrees, sharing the belief that their hard work will pay off in the form of greater security and wider opportunities. Neither was forthcoming in their experience, however: 'There's an expectation that you should be doing well now - an expectation that for a long time you shared since, after all, you had played your part and worked hard. So the struggle should 
have paid off by now, right? Sadly, that's not the case' (p. 297). The piece, written in the form of a letter to her younger self, signs off 'With love and sorrow' (p. 297).

Mitchell's essay suggests that this genre of writing and its conventions may shift significantly as a result of political and economic changes in Britain and the U.S. Whereas the genre has previously accommodated intense ambivalence about whether it was worth it, and whether the gains outweigh the losses associated with achieving upward mobility via education, the assumption has most always been that some measure of upward mobility was in fact achieved. As a reader, I was left wanting a way to check in on Mitchell in five, ten, twenty years from now, to see both how she fares economically and how she feels about and understands her pursuit of education.

Another strength of the volume is that a number of the contributors foreground their racial identity in relation to their class position and their educational experiences in ways that complicate and extend our understanding of what it means to pursue class mobility via education. Particularly moving are the narratives by Black women, two of whom identify themselves as children of parents of the Windrush generation. Those who watched Steve McQueen's 2020 film series Small Axe, particularly the film simply entitled 'Education,' will be familiar with aspects of their narratives. Christa Welsh, for example, writes that 'In the 1970s, second generation West Indian children were institutionally discriminated against. In Primary Schools, a disproportionate number of West Indian immigrant children were placed in classes for the 'Educationally Subnormal'. I was one of those children' (p. 131). The racism they faced as children (and continue to face as adults) is presented unflinchingly. In the educational setting, it manifested both overtly and more covertly, in the form of lowered expectations and expressions of disbelief at their accomplishments, as when Victoria Adukwei Bulley recounts being asked 'Is this yours? ... Did you write this?' She continues, 'I would often find this penned onto sheets of work that had been marked by teachers. Not so much a celebration of my work, more a sense of dissonance' (p. 286).

A final feature which makes this volume unique in the genre is that Goode gave the contributors a chance to read and respond to each other's essays. She then collated and edited those responses into an essay titled 'Clever Girls in Conversation' that appears right before the conclusion of the volume. Some of the responses to one another's pieces are cursory, which is understandable given that there are fourteen different contributors to the volume, but there is something undeniably powerful about staging this encounter with each other's words. According to Goode, the process of reading and responding to each other's essays 'felt transformative, turning the 'making' of the book into a collaborative autoethnography in itself that embodied more than the sum of its parts' (p. 14). I was reminded of Sherry Linkon's assertion that scholarly personal narratives, which she argues are the signature genre of the field of working-class studies, 'recount and analyze the centrality of belonging in workingclass culture, and they also help to create it.' In Clever Girls, Jackie Goode has pushed this aspect of the genre to a new level.

\section{Reviewer Bio}

Christie Launius is Associate Professor and Head of the Department of Gender, Women, and Sexuality Studies at Kansas State University. With Michele Fazio and Tim Strangleman, she co-edited the Routledge International Handbook of Working-Class Studies (2021). Her next project focuses on contemporary working-class memoirs. 